\title{
Studies on adsorption of phenol and 4-nitrophenol on MgAl-mixed oxide derived from MgAl-layered double hydroxide
}

\author{
Shuangling Chen ${ }^{\mathrm{a}}$, Zhi Ping Xu ${ }^{\mathrm{b}, *}$, Qian Zhang ${ }^{\mathrm{c}}$, G.Q. Max Lu ${ }^{\mathrm{b}, 1}$, Zheng Ping Hao ${ }^{\mathrm{d}}$, Shaomin Liu ${ }^{\mathrm{b}, 1}$ \\ a Department of Chemical Biology, School of Chemical Biology and Pharmaceutical Sciences, Capital University of Medical Sciences, Beijing 100069, PR China \\ ${ }^{\mathrm{b}}$ ARC Centre for Functional Nanomaterials, School of Engineering and Australian Institute for Bioengineering and Nanotechnology, \\ The University of Queensland, Brisbane, QLD 4072, Australia \\ c Department of Urology, Beijing Fuxing Hospital, Beijing 100038, PR China \\ ${ }^{\mathrm{d}}$ Research Center for Eco-Environmental Sciences, Chinese Academy of Sciences, Beijing 100085, PR China
}

\section{A R T I C L E I N F O}

\section{Keywords:}

Adsorption

Phenols

Layered double hydroxide (LDH)

Reconstruction

Isotherm

\begin{abstract}
A B S T R A C T
In this research, the removal of two phenols (4-nitrophenol and phenol) from aqueous solution was investigated using $\mathrm{MgAl}$-mixed oxide. This oxide was prepared by calcining crystalline $\mathrm{MgAl}-\mathrm{CO}_{3}$-layered double hydroxide (LDH) at $500^{\circ} \mathrm{C}$ for $4 \mathrm{~h}$. We found that it takes $10-12 \mathrm{~h}$ for adsorption of 4-nitrophenol to reach the equilibrium at room temperature while the equilibrium time is $20-25 \mathrm{~h}$ for phenol adsorption. The kinetic process of 4-nitrophenol adsorption seemingly follows the first-order reaction but phenol is adsorbed in a pseudo-second-order model. We also noted that the maximum adsorption amount of 4-nitrophenol by fitted three-parameter Langmuir-Freundlich isotherm is $367.8 \mathrm{mg} / \mathrm{g}$, much higher than that of phenol $(46.9 \mathrm{mg} / \mathrm{g})$. The differences in the adsorption kinetics and dynamics have been related to the adsorption mechanism and adsorbate-adsorbent interactions. The reconstruction of MgAl-mixed oxide in aqueous solution incorporates 4-nitrophenolate into the interlayer. However, it is difficult to intercalate phenolate due to its weaker affinity for $\mathrm{LDH}$ in comparison with $\mathrm{OH}^{-}$. In addition, adsorption of MgAl-mixed oxide for 4-nitrophenol and phenol is slightly affected by the initial pH, but considerably facilitated by increasing the adsorption temperature.
\end{abstract}

(c) 2009 Elsevier B.V. All rights reserved.

\section{Introduction}

Removal of the organic pollutants from wastewater before its discharge is necessary in order to reduce their side effect on the environment and human health. Various organic pollutants, in particular phenolic derivatives, are the products of many industrial processes and found in industrial wastewater. Phenolic derivatives, such as a number of chloro- and nitrophenols, are toxic and carcinogenic. They can persist for many years in the environment because of their resistance to microbiological degradation. In the last decade, various methods have been proposed to remove phenols, including catalytic oxidation [1,2], photo-oxidation [3], electrochemical oxidation [4], biological degradation [5], ultrafiltration [6] and adsorption [7-15]. Since the other methods need special process requirements or special catalysts, adsorption seems to be a good choice in terms of the cost and operation for the removal of phenolic compounds from wastewater.

\footnotetext{
* Corresponding author. Tel.: +61 7 33463809; fax: +61 733463973.

E-mail address: gordonxu@uq.edu.au (Z.P. Xu).

${ }^{1}$ Tel.: +61 733463809 ; fax: +61 733463973.
}

Various adsorbents were tested to adsorb the phenolic compounds in aqueous solution in the past years. For example, Roostaei and Tezel investigated phenol adsorption on silica gel, activated alumina, activated carbon and zeolites, the latter two materials show a higher capacity for the adsorption of phenol [12]. Rodriguez and co-workers found that activated carbons are good adsorbents for phenol and 2,4,5-trichlorophenol [9]. Some other materials, such as calcined layered double hydroxides $[11,15]$, dried sewage sludge [14], crosslinked starch polymers from an agro alimentary by-product [8], sewage treatment plant biosolids [7], coir pith carbon [16], crosslinked starch gels containing tertiary amine groups [8] and mesoporous silicate [10] were tested to remove phenol and substituted phenols from aqueous solution. In particular, the calcined MgAl-LDHs, i.e. MgAl-oxides, show an effective adsorption for substituted phenols in aqueous solution because such an oxide can be readily reconstructed to LDH structure, during which anionic phenolates are intercalated (incorporated), which was reported by Hermosin et al. [11] and Ulibarri et al. [15].

LDHs are a class of lamellar hydroxides that consist of brucitetype mixed metal hydroxide layers and exchangeable interlayer anions, with a general formula of $\left[\mathrm{M}_{1-x}{ }^{\mathrm{II}} \mathrm{M}_{x} \mathrm{III}(\mathrm{OH})_{2}\right]^{x+}\left(\mathrm{A}^{n-}\right)_{x / n}$. $m \mathrm{H}_{2} \mathrm{O}$, where $x=0.2-0.33, \mathrm{M}^{\mathrm{II}}$ and $\mathrm{M}^{\mathrm{III}}$ represent any divalent and trivalent metal cations and $\mathrm{A}^{n-}$ any anion $[17,18]$. One naturally 


\begin{tabular}{|ll|}
\hline \multicolumn{2}{|l|}{ Nomenclature } \\
$b$ & adsorption constant $(\mathrm{L} / \mathrm{mg})$ \\
$c_{0}$ & initial concentration of phenols $(\mathrm{mg} / \mathrm{L})$ \\
$c_{e}$ & equilibrium concentration of phenols $(\mathrm{mg} / \mathrm{L})$ \\
$k$ & Freundlich constant $\left((\mathrm{mg} / \mathrm{g})(\mathrm{L} / \mathrm{mg})^{1 / n}\right)$ \\
$k_{a d}$ & adsorption rate constant $(\mathrm{L} / \mathrm{h})$ \\
$\mathrm{LDH}$ & layered double hydroxide \\
$m$ & mass of MgAl-mixed oxide $(\mathrm{g})$ \\
$\mathrm{NO}_{2} \mathrm{PhOH}$ 4-nitrophenol \\
$\mathrm{NO}_{2} \mathrm{PhO}^{-}$deprotonated 4-nitrophenol \\
$\mathrm{PhOH}^{\mathrm{phenol}}$ \\
$\mathrm{PhO}^{-} \quad$ deprotonated phenol \\
$q_{e}$ & adsorption amount of phenols at the equilibrium \\
& (mg/g) \\
$q_{t}$ & adsorption amount of phenols at any time $t(\mathrm{mg} / \mathrm{g})$ \\
$\mathrm{Q}$ & maximum adsorption amount of phenols $(\mathrm{mg} / \mathrm{g})$ \\
$t$ & time $(\mathrm{h})$ \\
$V$ & solution volume $(\mathrm{L})$ \\
&
\end{tabular}

existing example is hydrotalcite $\left(\mathrm{Mg}_{3} \mathrm{Al}(\mathrm{OH})_{8}\left(\mathrm{CO}_{3}\right)_{1 / 2} \cdot 2 \mathrm{H}_{2} \mathrm{O}\right)$. $\mathrm{LDHs}$ and the related materials find a number of applications [17,18], such as ion exchangers [19], basic catalysts for organic synthesis $[17,18]$ and carriers for efficient cellular delivery $[20,21]$. In particular, after calcination at moderate temperatures $\left(450-650^{\circ} \mathrm{C}\right)$, $\mathrm{MgAl}-\mathrm{CO}_{3}-\mathrm{LDH}$ can be converted to a mixed metal oxide with a specific surface area of $\sim 200 \mathrm{~m}^{2} / \mathrm{g}$ and homogeneous dispersion of metal cations. The mixed metal oxide can be reconstructed in aqueous solution to regain the layered structure with different anions intercalated in the interlayer, and thus the MgAl-mixed oxide is a promising adsorbent to eliminate ecologically undesirable inorganic or organic anions $[17,18]$.

This research reports the adsorption behaviors of phenol $(\mathrm{PhOH})$ and 4-nitrophenol $\left(\mathrm{NO}_{2} \mathrm{PhOH}\right)$ on $\mathrm{MgAl}$-mixed oxide. We note that the derived $\mathrm{MgAl}$-mixed oxide is a potential adsorbent for some phenols in terms of the adsorption capacity.

\section{Materials and methods}

\subsection{Materials preparation}

Precursor $\mathrm{MgAl}-\mathrm{CO}_{3}$-LDHs were prepared by co-precipitation. Typically, a salt mixture solution $(200 \mathrm{~mL})$ containing $0.10 \mathrm{~mol}$ of $\mathrm{AlCl}_{3}$ and $0.20 \mathrm{~mol}$ of $\mathrm{MgCl}_{2}$ was added to an alkaline solution $(200 \mathrm{~mL})$ containing $0.60 \mathrm{~mol}$ of $\mathrm{NaOH}$ and $0.055 \mathrm{~mol}$ of $\mathrm{NaCO}_{3}$ under vigorous stirring. After further stirring for $10 \mathrm{~min}$, the slurry was collected and washed once with distilled water via centrifugation. The slurry was then dispersed in $400 \mathrm{~mL}$ distilled water, and then hydrothermally treated at $100^{\circ} \mathrm{C}$ for $4 \mathrm{~h}$. The $\mathrm{MgAl}-\mathrm{CO}_{3}-\mathrm{LDH}$ material was collected via high-speed centrifugation and dried at $50{ }^{\circ} \mathrm{C}$ overnight. As-prepared LDH material was then calcined in a muffle furnace at $500^{\circ} \mathrm{C}$ for $4 \mathrm{~h}$ to derive $\mathrm{MgAl}$-mixed oxide used as the adsorbent for the adsorption of $\mathrm{PhOH}$ and $\mathrm{NO}_{2} \mathrm{PhOH}$.

\subsection{Materials characterization}

X-ray diffraction (XRD) patterns of the LDH and the derived mixed oxide were collected on a powder X-ray diffractometer (XRD, Rigaku Miniflex with a variable slit width) with Co K $\alpha$ radiation $(\lambda=0.1790 \mathrm{~nm})$ at a scanning rate of $2^{\circ} / \mathrm{min}$ from $2 \theta=5^{\circ}$ to $2 \theta=80^{\circ}$. Infrared spectra were collected using $\mathrm{KBr}$ discs on a Perkin-Elmer 2000 FTIR after 40 scans within $4000-400 \mathrm{~cm}^{-1}$ at a resolution of $2 \mathrm{~cm}^{-1}$. The electron microscopic images were obtained on a JEOLJSM-6400F field emission scanning electron microscope (SEM) at an acceleration voltage of $10 \mathrm{kV}$. $\mathrm{Mg} / \mathrm{Al}$ ratio was analyzed by inductively coupled plasma-atomic emission spectroscopy (ICPAES) on a Varian Vista Pro. Thermogravimetric analysis (Shimatsu, $\mathrm{TG} 50 \mathrm{H}$ ) was carried out using air as the carrier gas at a flow rate of $100 \mathrm{~mL} / \mathrm{min}$. During the measurement, $10-20 \mathrm{mg}$ of LDH sample was heated at a rate of $10^{\circ} \mathrm{C} / \mathrm{min}$ over a temperature range of $30-800^{\circ} \mathrm{C}$.

\subsection{Adsorption of phenols}

Prior to adsorption, the MgAl-mixed oxide was pressed and crushed to the mesh size of 40-60. The isothermal adsorption experiments were carried out in batch under constant shaking. For the adsorption kinetics, MgAl-mixed oxide $(0.10 \mathrm{~g})$ was used to adsorb phenols at a concentration of $100 \mathrm{mg} / \mathrm{L}(20 \mathrm{~mL})$ at $\mathrm{pH} 10$ or 5 in a series of reaction tubes. The reaction tubes were immersed in a shaker and kept at room temperature $\left(22 \pm 2{ }^{\circ} \mathrm{C}\right)$ or at $55 \pm 2{ }^{\circ} \mathrm{C}$ under shaking. At a desired time point from 0 to $30 \mathrm{~h}, 1.0 \mathrm{~mL}$ of the supernatant was taken from the suspension. After filtration with a $0.22-\mu \mathrm{m}$ filter and high-speed centrifugation, the phenol concentration in the supernatant was determined with the UV absorption on a JASCO V-550 UV/vis spectrophotometer, and thus the adsorbed amount of phenols was calculated.

To test the phenol adsorption capability, MgAl-mixed oxide $(0.10 \mathrm{~g})$ was placed in a series of reaction tubes containing various concentrations $(10-2000 \mathrm{mg} / \mathrm{L})$ of $\mathrm{PhOH}$ or $\mathrm{NO}_{2} \mathrm{PhOH}(20 \mathrm{~mL})$. The suspensions were shaken at $22 \pm 2{ }^{\circ} \mathrm{C}$ for $30 \mathrm{~h}$ to reach the adsorption equilibrium, and then the supernatants were treated by filtering through a $0.22-\mu \mathrm{m}$ filter and high-speed centrifugation, followed by the UV measurement to determine the equilibrium concentration $\left(c_{e}\right.$ in $\mathrm{mg} / \mathrm{L}$ ) of the phenol that was not adsorbed. Therefore, the amount of phenols $\left(q_{e}\right.$ in $\mathrm{mg} / \mathrm{g}$ ) adsorbed on MgAlmixed oxide was calculated using Eq. (1):

$q_{e}=\frac{\left(c_{0}-c_{e}\right) V}{m}$

where $V$ is the volume of solution $(\mathrm{L}), c_{0}(\mathrm{mg} / \mathrm{L})$ and $c_{e}(\mathrm{mg} / \mathrm{L})$ the initial and equilibrium concentration of $\mathrm{PhOH}$ or $\mathrm{NO}_{2} \mathrm{PhOH}$, respectively, and $m$ the mass of adsorbent ( $\mathrm{g}$ ).

\section{Results and discussion}

\subsection{Structural properties}

As shown in Fig. 1, the complete transformation of crystalline $\mathrm{MgAl}-\mathrm{CO}_{3}-\mathrm{LDH}$ to $\mathrm{MgAl}-$ mixed oxide is reflected by the XRD patterns. $\mathrm{MgAl}-\mathrm{CO}_{3}-\mathrm{LDH}$ shows a series of the basal reflections from the (003), (006) planes, etc. and from plane (110) (Fig. 1A), with an interlayer spacing of $0.762 \mathrm{~nm}$ and unit cell parameter $a$ of $0.306 \mathrm{~nm}[17,18]$. After calcination at $500^{\circ} \mathrm{C}$, the crystalline LDH phase changes to $\mathrm{MgO}$ phase (JCPDS 43-1022) that is indicated by the two broad peaks at $52^{\circ}$ [plane (200)] and $75^{\circ}$ [plane (220)] (Fig. 1B). This transformation has been also confirmed by the FTIR spectra (see Supplementary Fig. S1).

Also shown in Fig. 2 are the SEM morphological images of the original LDH and the derived oxide. As-prepared LDH particles are featured in shape with the usual hexagonal platelets, with the lateral dimension being 100-200 $\mathrm{nm}$ and the thickness 20-30 $\mathrm{nm}$ [17]. After calcination, some big particles (in $1 \mu \mathrm{m}$ scale) are formed with certain shape, probably attributed to the aggregation during the calcination, while most oxide particles are much smaller and shapeless.

The elemental analysis from ICP-AES indicates that the $\mathrm{Mg} / \mathrm{Al}$ atomic ratio is 2.02. The approximate formula of as-prepared LDH is $\mathrm{Mg}_{2.02} \mathrm{Al}(\mathrm{OH})_{6.04}\left(\mathrm{CO}_{3}\right)_{0.5} \cdot 1.17 \mathrm{H}_{2} \mathrm{O}$, giving a total weight loss of $42.6 \%$ when converted to the mixed oxide $\left(\mathrm{Mg}_{2.02} \mathrm{AlO}_{3.52}\right)$, in good 


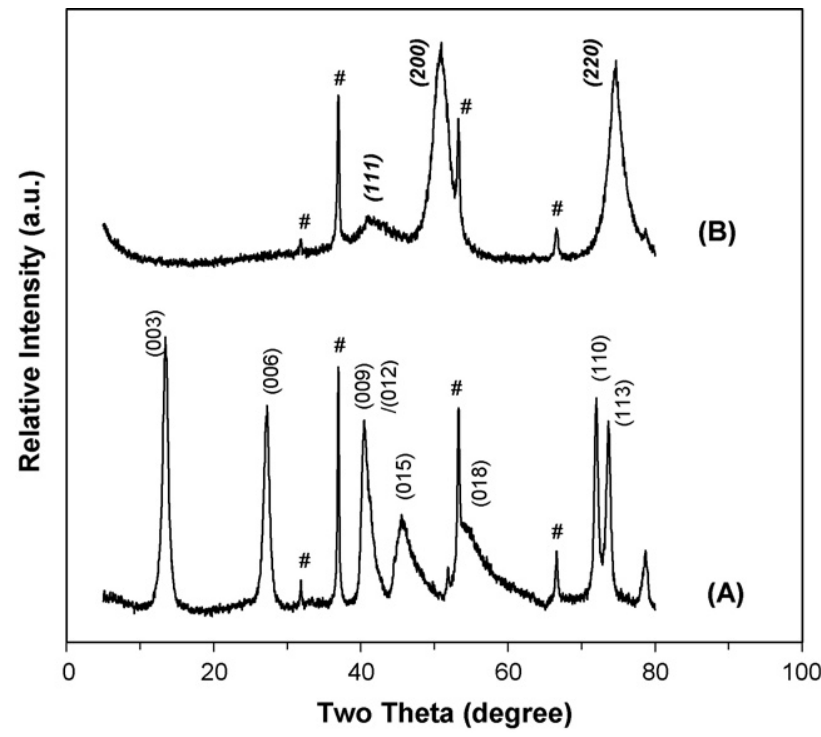

Fig. 1. XRD patterns of $(\mathrm{A}) \mathrm{MgAl}-\mathrm{CO}_{3}-\mathrm{LDH}$ and (B) $\mathrm{MgAl}$-mixed oxide. The diffraction peaks marked with $(\#)$ are attributed to the aluminum holder.

agreement with the weight loss $(42.5 \%)$ at $700^{\circ} \mathrm{C}$ measured by TGA (see Supplementary Fig. S2). The TGA data further indicate that calcination at $500^{\circ} \mathrm{C}$ for $4 \mathrm{~h}$ has completely converted as-prepared $\mathrm{MgAl}-\mathrm{CO}_{3}-\mathrm{LDH}$ to the mixed oxide since after $500^{\circ} \mathrm{C}$ there is no obvious weight loss step.

\subsection{Adsorption kinetics}

The adsorption of phenols from the liquid to solid phase was first investigated with the adsorption time. As shown in Fig. 3A, the adsorption of $\mathrm{NO}_{2} \mathrm{PhOH}$ continues to 10-12 h, and then keeps almost unchanged to $30 \mathrm{~h}$ at $\mathrm{pH}$ of both 5 and 10 . The adsorption behavior indicates that the adsorption on the MgAl-mixed oxide is not affected by the initial $\mathrm{pH}$ and reaches the equilibrium at $12 \mathrm{~h}$. The adsorbed amount of $\mathrm{NO}_{2} \mathrm{PhOH}$ at $12 \mathrm{~h}$ is $16-17 \mathrm{mg} / \mathrm{g}$, indicating that $80-85 \%$ of initial $\mathrm{NO}_{2} \mathrm{PhOH}$ is removed by $\mathrm{MgAl}$-oxide under the current conditions. In contrast, $\mathrm{MgAl}$-oxide continues to adsorb $\mathrm{PhOH}$ till 20-25 h. Although the initial pH does not affect $\mathrm{PhOH}$ adsorption behavior, the adsorbed amount of $\mathrm{PhOH}$ on the same mixed oxide is much smaller, $1.4-1.5 \mathrm{mg} / \mathrm{g}$ at $15 \mathrm{~h}$, corresponding to $7-7.5 \%$ of the initial $\mathrm{PhOH}$ in the solution.

We used the first-order Lagergren equation (Eq. (2)) and the pseudo-second-order equation (Eq. (3)) $[13,22]$ to treat the adsorption of phenols over the $\mathrm{MgAl}$-mixed oxide in aqueous solution:

$\log \left(q_{e}-q_{t}\right)=\log q_{e}-\frac{k_{a d}}{2.303} t$

$\frac{t}{q_{t}}=\frac{1}{k_{a d} q_{e}^{2}}+\frac{1}{q_{e}} t$

where $q_{e}$ and $q_{t}$ are amounts of phenols adsorbed by the adsorbent $(\mathrm{mg} / \mathrm{g})$ at the equilibrium time and time $t$, respectively, and $k_{a d}$ the adsorption rate constant. Adsorption data were fitted by both equations, and we found that the first-order Lagergren model is more suitable for the adsorption of $\mathrm{NO}_{2} \mathrm{PhOH}$ while the pseudo-secondorder model is better for PhOH adsorption. As shown in Fig. 4A, the first-order Lagergren kinetic model gives a straight line in the plots of $q_{t}$ vs. $t$ at $\mathrm{pH} 5$ and 10 for $\mathrm{NO}_{2} \mathrm{PhOH}$ adsorption. On the other hand, the linearity of the plots of $t / q_{t}$ vs. $t$ shows a better agreement with the pseudo-second-order model for the PhOH adsorption (Fig. 4B). The fitting parameters are listed in Table 1 . We note again that the initial $\mathrm{pH}$ has little effect on these parameters and that the equi-
(A)

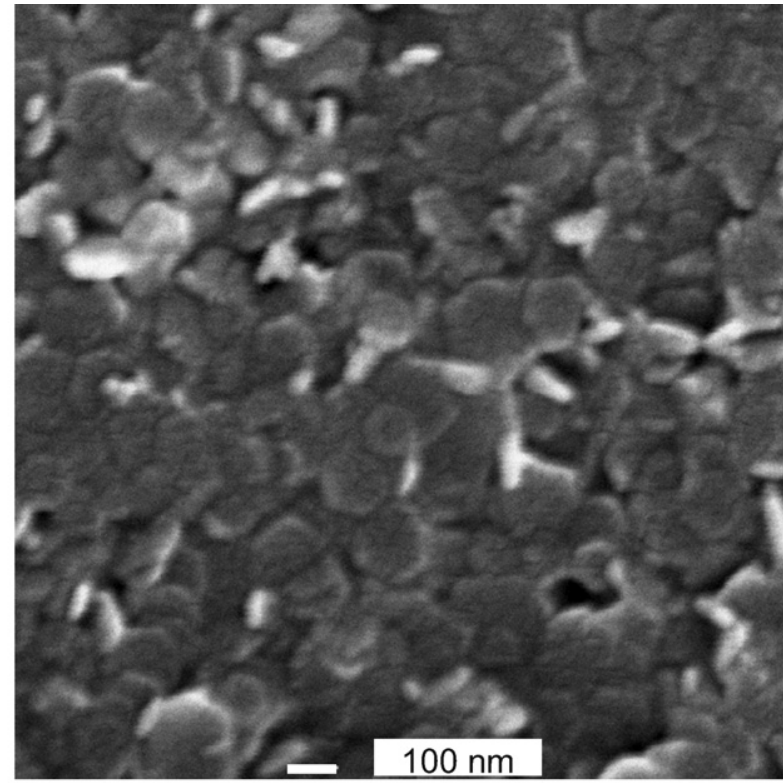

(B)

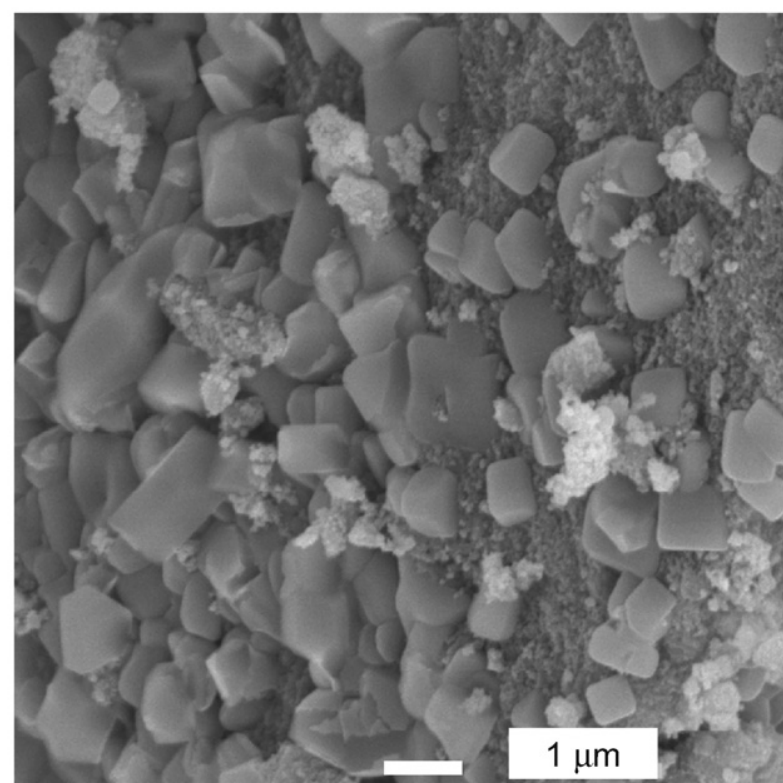

Fig. 2. SEM images of (A) MgAl- $\mathrm{CO}_{3}-\mathrm{LDH}$ and (B) derived $\mathrm{MgAl}$-mixed oxide.

librium adsorption amount for $\mathrm{NO}_{2} \mathrm{PhOH}$ is $5-10$ times as that for $\mathrm{PhOH}$.

\subsection{Adsorption capability for phenols}

To examine the adsorption capability of MgAl-mixed oxide for phenols in aqueous solution, we carried out a series of equilibrium adsorption tests ( $30 \mathrm{~h}$ at room temperature) by varying phenol concentration from 10 to $2000 \mathrm{ppm}$. The adsorption data are shown in Fig. 5. We employed three isotherm models to treat the adsorption data [12]. The three models are:

Langmuir isotherm : $\quad q_{e}=\frac{Q b c_{e}}{1+b c_{e}}$

where $Q(\mathrm{mg} / \mathrm{g})$ and $b(\mathrm{~L} / \mathrm{mg})$ are the Langmuir constants related to the loading and energy of adsorption.

Freundlich isotherm : $q_{e}=k c^{1 / n}$ 
Table 1

Fitting parameters for the adsorption kinetic models.

\begin{tabular}{|c|c|c|c|c|c|}
\hline Adsorbate & Model & Initial $\mathrm{pH}$ & $q_{e}(\mathrm{mg} / \mathrm{g})$ & $k_{a d}(\mathrm{~L} / \mathrm{h})$ & $R^{2}$ \\
\hline 4-Nitrophenol & Lagergren first-order & $\begin{array}{r}5 \\
10\end{array}$ & $\begin{array}{l}17 \\
16.6\end{array}$ & $\begin{array}{l}0.175 \\
0.125\end{array}$ & $\begin{array}{l}0.972 \\
0.972\end{array}$ \\
\hline Phenol & Pseudo-second-order & $\begin{array}{r}5 \\
10\end{array}$ & $\begin{array}{l}2.74 \\
1.51\end{array}$ & $\begin{array}{l}0.351 \\
0.154\end{array}$ & $\begin{array}{l}0.996 \\
0.978\end{array}$ \\
\hline
\end{tabular}

where $k\left[(\mathrm{mg} / \mathrm{g})(\mathrm{L} / \mathrm{mg})^{1 / n}\right]$ and $n$ are the Freundlich temperaturedependent constants.

Three-parameter Langmuir-Freundlich isotherm :

$q_{e}=Q \frac{\left(b c_{e}\right)^{1 / n}}{1+\left(b c_{e}\right)^{1 / n}}$

where $Q(\mathrm{mg} / \mathrm{g})$ is the maximum adsorption amount, $b(\mathrm{~L} / \mathrm{mg})$ and $1 / n$ are constants related to the adsorption strength. In addition, $c_{e}$ is the equilibrium concentration of phenols $(\mathrm{mg} / \mathrm{L})$, and $q_{e}(\mathrm{mg} / \mathrm{g})$ the adsorption amount on $\mathrm{MgAl}$-mixed oxide at the equilibrium.

As shown in Fig. 5, the adsorption data of both phenols are better fitted with three-parameter Langmuir-Freundlich isotherm (solid line), which is also reflected by the higher regression coefficient in Table 2. In addition, Freundlich isotherm seems good for $\mathrm{PhOH}$ adsorption while Langmuir is better for $\mathrm{NO}_{2} \mathrm{PhOH}$. Further note that the maximum adsorption capability of the mixed oxide for $\mathrm{NO}_{2} \mathrm{PhOH}$ is $367.8 \mathrm{mg} / \mathrm{g}$ from three-parameter Langmuir-Freundlich isotherm, quite close to the real experimental adsorption capacity $(360-380 \mathrm{mg} / \mathrm{g})$ at the concentration range of $500-1700 \mathrm{mg} / \mathrm{L}$. This amount is much bigger than that for $\mathrm{PhOH}$ $(46.9 \mathrm{mg} / \mathrm{g})$ that is almost double the real adsorption capacity at the concentration of $c a .700 \mathrm{mg} / \mathrm{L}$. We also note that other parame-
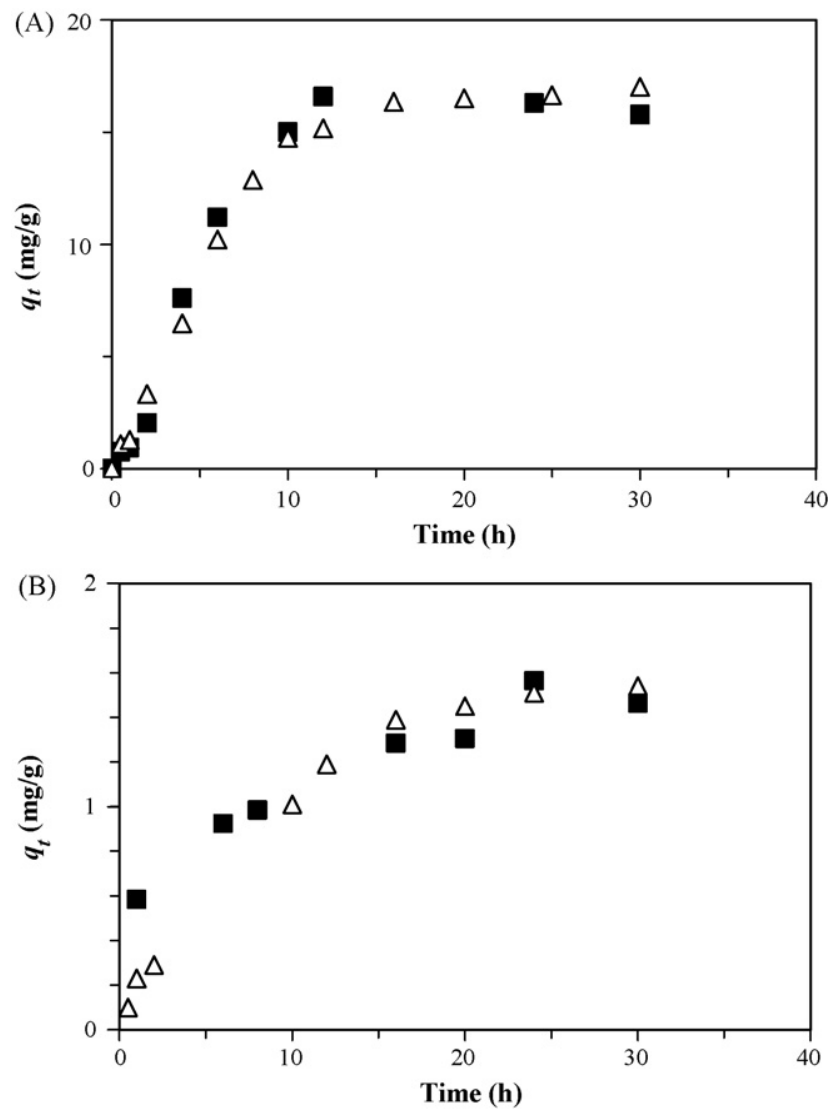

Fig. 3. Adsorption amount of $(\mathrm{A}) \mathrm{NO}_{2} \mathrm{PhOH}$ and (B) $\mathrm{PhOH}$ on $\mathrm{MgAl}$-oxide at $\mathrm{pH} 10$ $(\boldsymbol{\square})$ and $\mathrm{pH} 5(\Delta)$ as a function of adsorption time. ters are quite different for two phenols (Table 2). The differences in the fitting parameters as well as in the adsorption behaviors presented previously suggest that these two phenols are adsorbed by two different mechanisms, as addressed shortly.

In comparison, LDH-derived MgAl-mixed oxide seems to be a very good adsorbent for some phenolic compounds. Ulibarri et al. showed that MgAl-mixed oxide can effectively adsorb 2,4,6trinitrophenol, with the adsorbed amount up to $2.25 \mathrm{mmol} / \mathrm{g}$ ( $c a$. $550 \mathrm{mg} / \mathrm{g}$ ) [11,15]. The current research finds that MgAl-mixed oxide can take up ca. $370 \mathrm{mg} / \mathrm{g} \mathrm{NO} \mathrm{N}_{2} \mathrm{PhOH}$ (ca. $2.3 \mathrm{mmol} / \mathrm{g}$ ). Such an adsorption capability is higher than most common adsorbents [8], except for some activated carbons [9]. However, the adsorption for $\mathrm{PhOH}$ is not so effective, in comparison with other adsorbents $[9,12,13]$.

The adsorption of two phenols on MgAl-mixed oxide is influenced to a large extent by the adsorption temperature. Our experimental tests show that the adsorption amount of MgAlmixed oxide for both phenols at $55^{\circ} \mathrm{C}$ for $0.5 \mathrm{~h}$ is remarkably increased, by ca. 10 times of that at $22^{\circ} \mathrm{C}$. The higher temperature speeds the phenol adsorption rate and probably the adsorption capacity, as discussed in the following section.
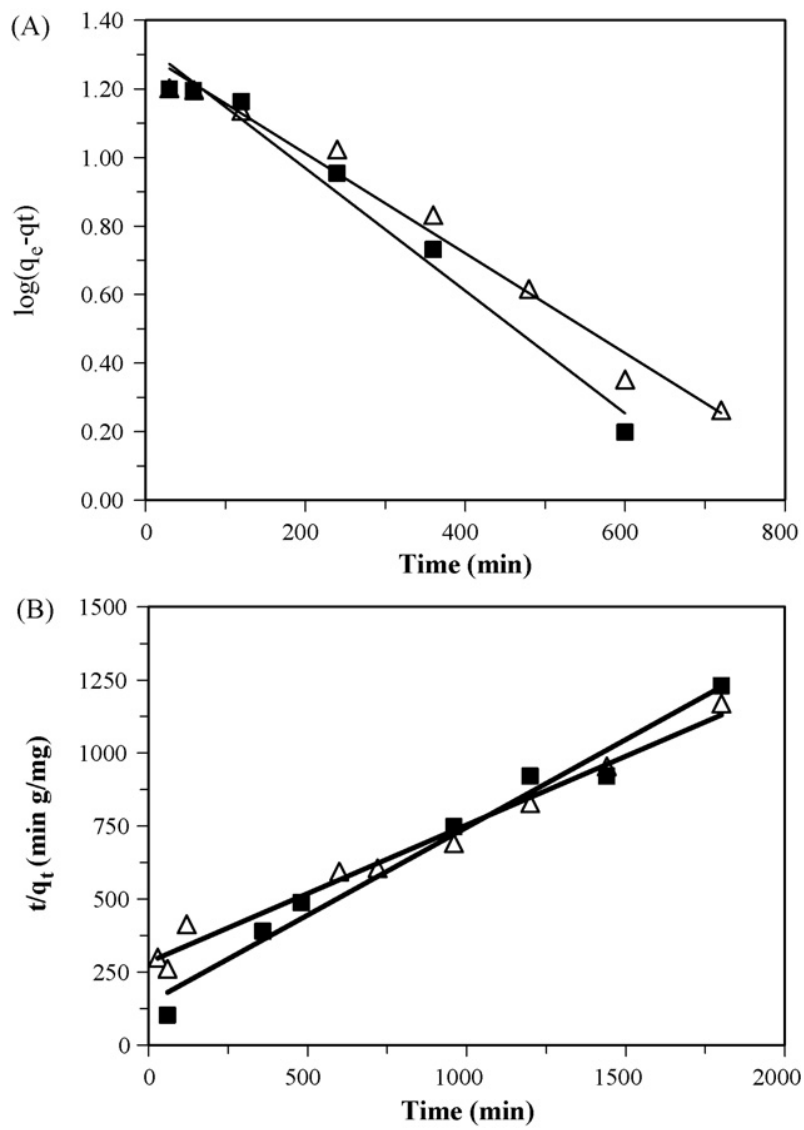

Fig. 4. (A) Lagergren first-order rate equation for adsorption of 4-nitrophenol and (B) pseudo-second-order rate equation for adsorption of phenol at $\mathrm{pH} 10(\boldsymbol{\square})$ and $\mathrm{pH}$ $5(\Delta)$. 
Table 2

Fitting parameters from different equilibrium models.

\begin{tabular}{|c|c|c|c|c|c|c|c|c|c|c|}
\hline \multirow[t]{2}{*}{ Adsorbate } & \multicolumn{4}{|c|}{ Three-parameter Langmuir-Freundlich } & \multicolumn{3}{|l|}{ Langmuir } & \multicolumn{3}{|l|}{ Freundlich } \\
\hline & $Q(\mathrm{mg} / \mathrm{g})$ & $b(\mathrm{~L} / \mathrm{mg})$ & $1 / n$ & $R^{2}$ & $Q(\mathrm{mg} / \mathrm{g})$ & $b(\mathrm{~L} / \mathrm{mg})$ & $R^{2}$ & $k\left((\mathrm{mg} / \mathrm{g})(\mathrm{L} / \mathrm{mg})^{1 / n}\right)$ & $1 / n$ & $R^{2}$ \\
\hline 4-Nitrophenol & 367.8 & 0.0179 & 4.667 & 0.998 & 439.7 & 0.00549 & 0.974 & 16.5 & 0.435 & 0.874 \\
\hline Phenol & 46.9 & 0.00166 & 2.225 & 0.999 & 134.1 & 0.00030 & 0.911 & 0.0016 & 1.497 & 0.993 \\
\hline
\end{tabular}

\subsection{Adsorption mechanism}

It is well known that the MgAl-mixed oxide derived by calcining its LDH precursor at mild temperatures can be readily reconstructed to regain the similar LDH structure in aqueous or basic solution $[17,18,23,24]$. As shown in Fig. $6 \mathrm{~A}$, the MgAl-mixed oxide starts to show the layered feature after shaking in basic solution $(\mathrm{pH} \mathrm{10)}$ for $4 \mathrm{~h}$ at room temperature, and the mixed oxide phase disappears after $16 \mathrm{~h}$ immersing. As for the adsorption of $\mathrm{NO}_{2} \mathrm{PhOH}$ on the MgAl-mixed oxide, two reactions presumably take place simultaneously:

$\mathrm{Mg}_{2} \mathrm{AlO}_{3.5}+(3.5+m) \mathrm{H}_{2} \mathrm{O} \rightarrow \mathrm{Mg}_{2} \mathrm{Al}(\mathrm{OH})_{6}(\mathrm{OH}) \cdot m \mathrm{H}_{2} \mathrm{O}$

$\mathrm{Mg}_{2} \mathrm{AlO}_{3.5}+(3.5+m) \mathrm{H}_{2} \mathrm{O}+\mathrm{NO}_{2} \mathrm{PhO}^{-}$

$\rightarrow \mathrm{Mg}_{2} \mathrm{Al}(\mathrm{OH})_{6}\left(\mathrm{NO}_{2} \mathrm{PhO}\right) \cdot m \mathrm{H}_{2} \mathrm{O}+\mathrm{OH}^{-}$
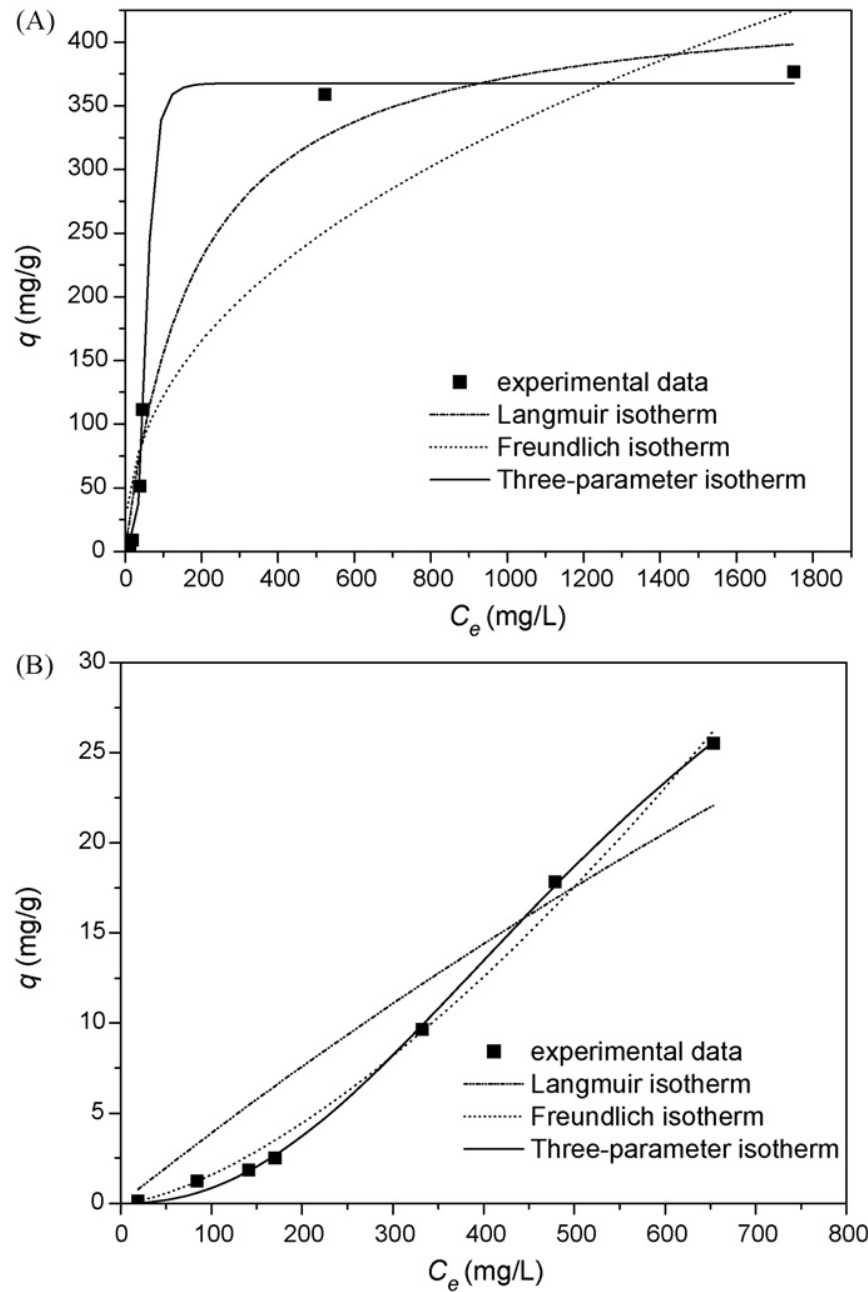

Fig. 5. Adsorption isotherms of (A) 4-nitrophenol and (B) phenol on Mg-Al-mixed oxide.
At pH 10 most $\mathrm{NO}_{2} \mathrm{PhOH}\left(\mathrm{p} K_{\mathrm{a}}=7.2\right)$ dissociates into the anionic form, and some can be intercalated into the interlayer space in the reconstructed $\mathrm{LDH}$. The intercalation of $\mathrm{NO}_{2} \mathrm{PhO}^{-}$is evidenced by the FTIR spectrum in Fig. 7A. The bands at 1592 and $1311 \mathrm{~cm}^{-1}$ indicate the presence of conjugated $\mathrm{NO}_{2}$ group, and the band at $1171 \mathrm{~cm}^{-1}$ is due to an $\mathrm{N}^{+}-\mathrm{O}^{-}$vibration of the $\mathrm{NO}_{2}$ group. As suggested by Ragavan et al. [25], the intercalation of $\mathrm{NO}_{2} \mathrm{PhOH}$ into $\mathrm{LDH}$ is facilitated by the electrostatic interaction between $-\mathrm{NO}_{2}$ group and the hydroxide layer. As presented previously, the maximum adsorption amount of $\mathrm{NO}_{2} \mathrm{PhOH}$ on $\mathrm{MgAl}$-mixed oxide is $\mathrm{ca}$. $367.8 \mathrm{mg} / \mathrm{g}$ (Table 2), representing ca. 35\% intercalation degree in the reconstructed $\mathrm{LDH}$. This suggests that the affinity of $\mathrm{NO}_{2} \mathrm{PhO}^{-}$ is similar to $\mathrm{OH}^{-}$since at the end of adsorption the concentrations of $\mathrm{NO}_{2} \mathrm{PhO}^{-}$and $\mathrm{OH}^{-}$are all in the range of 3-8 $\mathrm{mM}$ (suppose initial $\mathrm{NO}_{2} \mathrm{PhOH}$ is $1000 \mathrm{mg} / \mathrm{L}$ ).

As for the $\mathrm{PhOH}$ adsorption, we found that its maximum adsorption amount is ca. $46.9 \mathrm{mg} / \mathrm{g}$ from the three-parameter model, while the real amount is $25.5 \mathrm{mg} / \mathrm{g}$ (Fig. 5B). The latter amount is only corresponding to $3.6 \%$ intercalation degree in the reconstructed $\mathrm{LDH}$ if any. In the FTIR spectrum of the oxide after adsorption (Fig. 7B), we cannot observe any characteristic vibration bands of $\mathrm{PhOH}$, but a peak at $1365 \mathrm{~cm}^{-1}$ which is exclusively attributed to the $\mathrm{CO}_{3}{ }^{2-}$

(A)

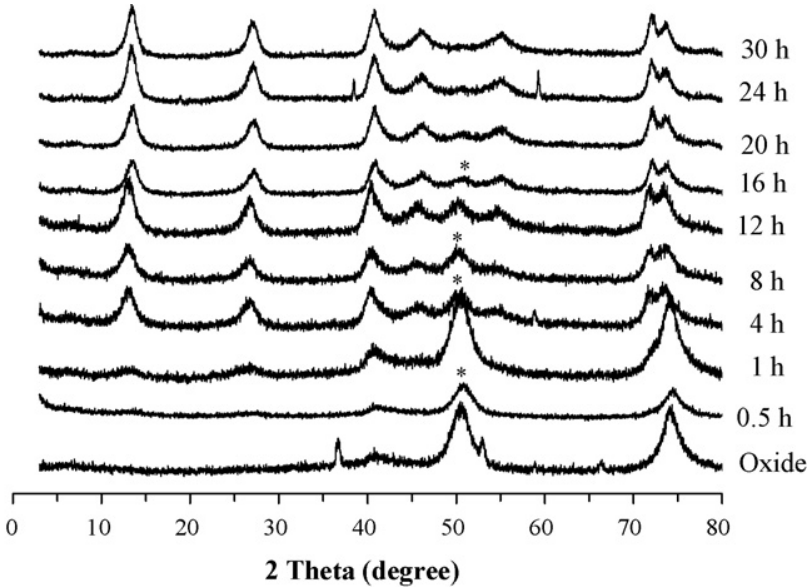

(B)

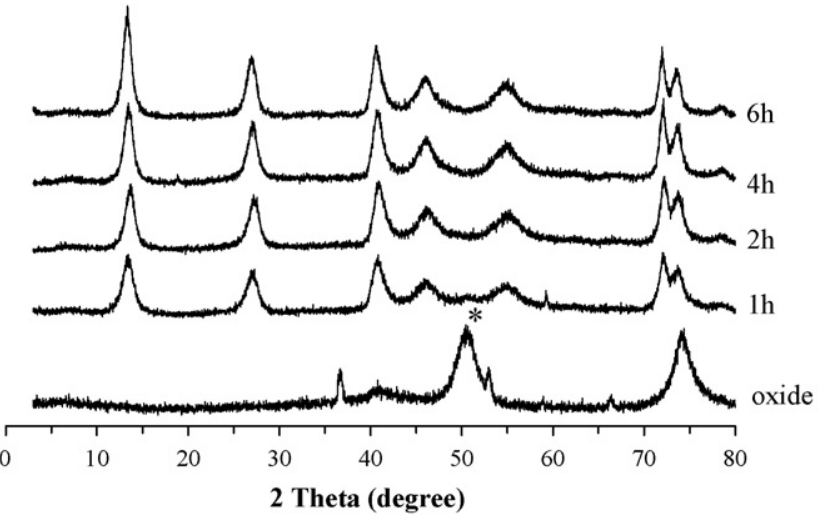

Fig. 6. XRD patterns of MgAl-mixed oxide as a function of the immersing time in water at $\mathrm{pH} 10$ at $22^{\circ} \mathrm{C}(\mathrm{A})$ and at $55^{\circ} \mathrm{C}(\mathrm{B})$. 


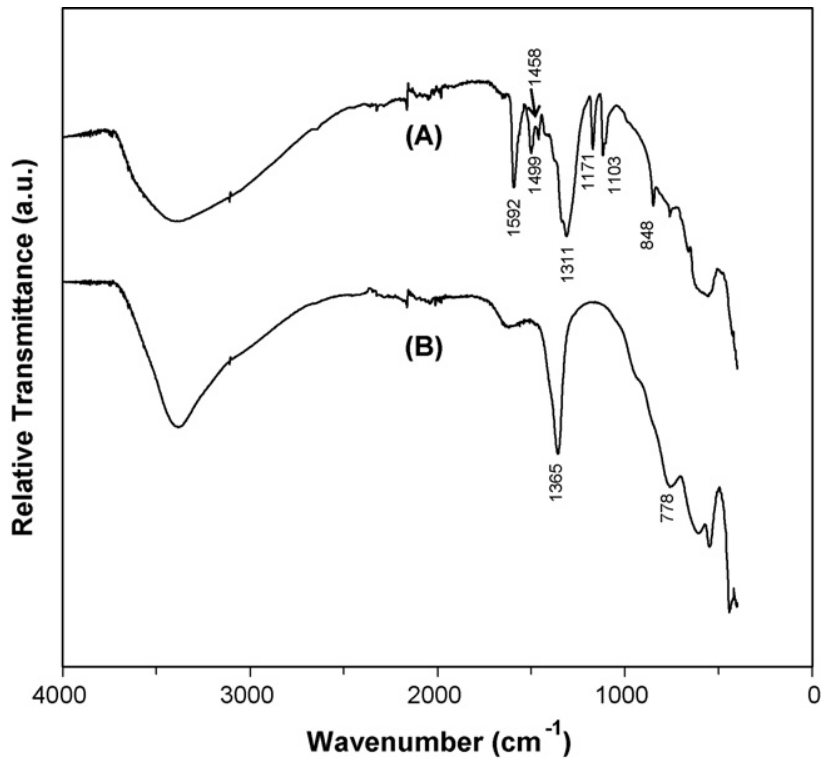

Fig. 7. FTIR spectra of MgAl-oxide after adsorption of (A) 4-nitrophenol and (B) phenol for $30 \mathrm{~h}$.

[17]. During the adsorption of $\mathrm{PhOH}, \mathrm{CO}_{2}$ contamination cannot be avoided, in particular under the basic condition ( $\mathrm{pH} 10-11)$. The preference for $\mathrm{CO}_{3}{ }^{2-}$ by $\mathrm{LDH}$ thus reduces the possibility for intercalation of both phenols. Unlike $\mathrm{NO}_{2} \mathrm{PhOH}$, the bulky hydrophobic phenyl ring in $\mathrm{PhOH}$ cannot provide any electrostatic interaction with the hydroxide layer, so phenolate has a very weaker affinity for $\mathrm{LDH}$ and its intercalation is more difficult than $\mathrm{NO}_{2} \mathrm{PhOH}$. Therefore, the affinity of phenolate for LDH is believed to be much weaker than $\mathrm{OH}^{-}$. Although more than $60 \%$ of $\mathrm{PhOH}$ can dissociate to phenolate anion at $\mathrm{pH} 10-11\left(\mathrm{p} K_{\mathrm{a}}=9.8\right)$, the phenolate intercalation degree if any (3.6\%) is much smaller than the $\mathrm{NO}_{2} \mathrm{PhO}^{-}(35 \%)$, and most phenolates stay in the aqueous phase. In this connection, the adsorbed $\mathrm{PhOH}$ is possibly situated only on the surface, not intercalated into the interlayers, which involves an adsorption mechanism different from $\mathrm{NO}_{2} \mathrm{PhOH}$, as suggested by their adsorption behaviors (Fig. 4), the equilibrium adsorption profiles (Fig. 5) and the fitted parameters (Tables 1 and 2).

The $\mathrm{LDH}$ reconstruction is also dependent on the temperature. As shown in Fig. 6B, the LDH structure is well established after $1 \mathrm{~h}$ shaking in the basic water $(\mathrm{pH} 10)$ at $55^{\circ} \mathrm{C}$, and the mixed oxide phase is gone after $2 \mathrm{~h}$ reaction. The temperature facilitation of LDH structure regeneration from the mixed oxide has also been observed by Millange et al. through a time-resolved in situ XRD investigation [24]. The quick regeneration of LDH structure thus speeds up the phenol adsorption and probably increases the adsorption capacity by reducing the adsorption time and capturing less $\mathrm{CO}_{2}$ from air.

We observed that the initial $\mathrm{pH}$ has a negligible effect on the adsorption for both phenols. This is because the initial $\mathrm{pH}(5.0)$ is quickly increased to 9-10 (see Supplementary Fig. S3). When the initial $\mathrm{pH}$ is 5.0 , the pH sharply jumps to 9.9 after $1 \mathrm{~h}$ reconstruction and then gradually increases to 11.4 after $30 \mathrm{~h}$. If the initial $\mathrm{pH}$ is 10 , the $\mathrm{pH}$ is slightly increased to 11.5 during the reconstruction [15]. After $2 \mathrm{~h}$ reconstruction, the $\mathrm{pH}$ difference in these two cases becomes very limited, and this is the main reason why the adsorption of MgAl-mixed oxide for two phenols is less affected by the initial $\mathrm{pH}$.

\section{Conclusions}

The present study shows that MgAl-mixed oxide, derived from its $\mathrm{LDH}$ precursor, is a potential adsorbent for the removal of
$\mathrm{NO}_{2} \mathrm{PhOH}$ as well as $\mathrm{PhOH}$ from aqueous solution. The adsorption capacity of MgAl-mixed oxide can be as high as $367.8 \mathrm{mg} / \mathrm{g}$ for $\mathrm{NO}_{2} \mathrm{PhOH}$ and $25.5 \mathrm{mg} / \mathrm{g}$ for $\mathrm{PhOH}$ at room temperature. Much more $\mathrm{NO}_{2} \mathrm{PhOH}$ molecules are adsorbed due to the strong electrostatic interaction between the $\mathrm{NO}_{2}$ group and the hydroxide layer of reconstructed MgAl-LDH. These two phenols show different adsorption kinetics on $\mathrm{MgAl}$-oxide, with $\mathrm{NO}_{2} \mathrm{PhOH}$ adsorbed according to the Lagergren first-order model while $\mathrm{PhOH}$ best fits the pseudo-second-order model. The Langmuir model well fits the equilibrium isotherm of $\mathrm{NO}_{2} \mathrm{PhOH}$ whereas the Freundlich model fits the $\mathrm{PhOH}$ adsorption, and furthermore both phenols follow the three-parameter Langmuir-Freundlich isotherm. We find that it takes $10-20 \mathrm{~h}$ for the phenol adsorption to reach equilibrium at room temperature, but heating to $50-60^{\circ} \mathrm{C}$ can shorten the equilibrium time to a few hours. The adsorption mechanism involves the reconstruction of MgAl-mixed oxide, during which $\mathrm{NO}_{2} \mathrm{PhO}^{-}$is intercalated into the interlayer while $\mathrm{PhO}^{-}$is mainly adsorbed on the surface.

\section{Acknowledgements}

Funding from the Australian Research Council for the ARC Centre for Functional Nanomaterials and UQ Early Career Researcher Grant (2004001428) is gratefully acknowledged.

\section{Appendix A. Supplementary data}

Supplementary data associated with this article can be found, in the online version, at doi:10.1016/j.seppur.2009.03.016.

\section{References}

[1] S.S. Gupta, et al., Rapid total destruction of chlorophenols by activated hydrogen peroxide, Science 296 (2002) 326-328.

[2] R.-M. Liou, S.-H. Chen, M.-Y.Hung, C.-S. Hsu, J.-Y. Lai, Fe (III) supported on resin as effective catalyst for the heterogeneous oxidation of phenol in aqueous solution, Chemosphere 59 (2005) 117-125.

[3] S.G. Poulopoulos, F. Arvanitakis, C.J. Philippopoulos, Photochemical treatment of phenol aqueous solutions using ultraviolet radiation and hydrogen peroxide, J. Hazard. Mater. 129 (2006) 64-68.

[4] P. Canizares, J. Lobato, R. Paz, M.A. Rodrigo, C. Saez, Electrochemical oxidation of phenolic wastes with boron-doped diamond anodes, Water. Res. 39 (2005) 2687-2703.

[5] T. Hatta, O. Nakano, N. Imai, N. Takizawa, H. Kiyohara, Cloning and sequence analysis of hydroxyquinol 1,2-dioxygenase gene in 2,4,6-trichlorophenoldegrading Ralstonia pickettii DTP0602 and characterization of its product, J. Biosci. Bioeng. 87 (1999) 267-272.

[6] J.L. Acero, F.J. Benitez, A.I. Leal, F.J. Real, Removal of phenolic compounds in water by ultrafiltration membrane treatments, J. Environ. Sci. Health A: Toxicol. Hazard. Subst. Environ. Eng. 40 (2005) 1585-1603.

[7] M.Z. Alam, Biosorption of phenol from aqueous solution by biosolids, Med. J. Malays. 59 (Suppl. B) (2004) 216-217.

[8] F. Delval, G. Crini, J. Vebrel, Removal of organic pollutants from aqueous solutions by adsorbents prepared from an agroalimentary by-product, Bioresour. Technol. 97 (2006) 2173-2181.

[9] E. Gonzalez-Serrano, T. Cordero, J. Rodriguez-Mirasol, L. Cotoruelo, J.J Rodriguez, Removal of water pollutants with activated carbons prepared from $\mathrm{H}_{3} \mathrm{PO}_{4}$ activation of lignin from kraft black liquors, Water Res. 38 (2004) 3043-3050.

[10] H. Hashizume, Adsorption of some aromatic compounds by a synthetic mesoporous silicate, J. Environ. Sci. Health A: Toxicol. Hazard. Subst. Environ. Eng. 39 (2004) 2615-2625.

[11] M.C. Hermosin, I. Pavlovic, M.A. Ulibarri, J. Cornejo, Hydrotalcite as sorbent for trinitrophenol sorption capacity and mechanism. Water Res. 30(1996)171-177.

[12] N. Roostaei, F.H. Tezel, Removal of phenol from aqueous solutions by adsorption, J. Environ. Manage. 70 (2004) 157-164.

[13] S. Senal, A. Kara, G. Alsancak, A. Denizli, Removal of phenol and chlorophenols from water with reusable dye-affinity hollow fibers, J. Hazard. Mater. B 138 (2006) 317-324.

[14] U. Thawornchaisit, K. Pakulanon, Application of dried sewage sludge as phenol biosorbent, Bioresour. Technol. 98 (2007) 140-144.

[15] M.A. Ulibarri, I. Pavlovic, M.C. Hermosin, J. Cornejo, Hydrotalcite-like compounds as potential sorbents of phenols from water, Appl. Clay Sci. 10 (1995) 131-145.

[16] C. Namasivayam, D. Kavitha, Removal of phenol and chlorophenols from water by coir pith carbon: equilibrium and rate studies, J. Environ. Sci. Eng. 46 (2004) 217-232. 
[17] P.S. Braterman, Z.P. Xu, F. Yarberry, Layered double hydroxides, in: S.M. Auerbach, K.A. Carrado, P.K. Dutta (Eds.), Handbook of Layered Materials, Marcel Dekker, Inc., New York, 2004, pp. 373-474.

[18] F. Cavani, F. Trifiro, A.Vaccari, Hydrotalcite-like anionic clays: preparation, properties and applications, Catal. Today 11 (1991) 173-301.

[19] R.P. Bontchev, S. Liu, J.L. Krumhansl, J. Voigt, T.M. Nenoff, Synthesis, characterization, and ion exchange properties of hydrotalcite $\mathrm{Mg}_{6} \mathrm{Al}_{2}(\mathrm{OH})_{16}(\mathrm{~A}) x\left(\mathrm{~A}^{\prime}\right)_{2-x} \cdot 4 \mathrm{H}_{2} \mathrm{O}\left(\mathrm{A}, \mathrm{A}^{\prime}\right) \mathrm{Cl}^{-}, \mathrm{Br}^{-}, \mathrm{I}^{-}$, and $\mathrm{NO}_{3}^{-}, 2 \geq x \geq 0$ derivatives, Chem. Mater. 15 (2003) 3669-3675.

[20] Z.P. Xu, G.Q.M. Lu, Layered double hydroxide nanomaterials as potential cellular drug delivery agents, Pure Appl. Chem. 78 (2006) 1771-1779.

[21] Z.P. Xu, Q.H. Zeng, G.Q.M. Lu, A.B. Yu, Inorganic nanoparticles as carriers for efficient cellular delivery, Chem. Eng. Sci. 61 (2006) 1027-1040.
[22] Y.S. Ho, G. McKay, Pseudo-second order model for sorption processes, Process Biochem. 34 (1999) 451-465.

[23] F. Delorme, A. Seron, M. Bizi, V. Jean-Prost, D. Martineau, Effect of time on the reconstruction of the $\mathrm{Mg}_{4} \mathrm{Al}_{2}(\mathrm{OH})_{12} \mathrm{CO}_{3} \cdot 3 \mathrm{H}_{2} \mathrm{O}$ layered double hydroxide in $\mathrm{NaCO}_{3}$ solution, J. Mater. Sci. 41 (2006) 4875-4882.

[24] F. Millange, R.I. Walton, D. O'Hare, Time-resolved in situ X-ray diffraction study of the liquid-phase reconstruction of $\mathrm{Mg}$-Al-carbonate hydrotalcite-like compounds, J. Mater. Chem. 10 (2000) 1713-1720.

[25] A. Ragavan, A.I. Khan, D. O'Hare, Isomer selective ion-exchange intercalation of nitrophenolates into the layered double hydroxide $\left[\mathrm{LiAl}_{2}(\mathrm{OH})_{6}\right] \mathrm{Cl} \cdot x \mathrm{H}_{2} \mathrm{O}, \mathrm{J}$ Mater. Chem. 16 (2006) 602-608. 